\title{
Accumulation of phosphorus in coastal marine sediments: relationship to benthic and diffusive fluxes
}

\author{
ROCIO PONCE, TEODORA ORTEGA, JESÚS M. FORJA and \\ ABELARDO GÓMEZ-PARRA \\ Facultad de Ciencias del Mar, Universidad de Cádiz. Polígono Río San Pedro s/n, E-11510 Puerto Real, Cádiz, Spain. \\ E-mail: rocio.ponce@uca.es
}

\begin{abstract}
SUMMARY: Sedimentary phosphorus was characterized in sediment cores from 3 coastal ecosystems of the Gulf of Cadiz. High spatial variability was observed in total phosphorus (from 445 to $20291 \mu \mathrm{g} \mathrm{g.sed}^{-1}$ ) and in the other phosphorus phases studied. This variability correlates with the proximity of the 10 sampling stations to sources of urban and/or industrial effluent in the zone. The benthic and diffusive fluxes were measured concurrently with sediment collection at these stations. The measured values of benthic fluxes range between -14 and $6 \mathrm{mmol} \mathrm{m}^{-2} \mathrm{~d}^{-1}$. Generally, stations that showed increased interstitial phosphate concentrations with increasing depth were characterized by positive values in phosphate benthic fluxes and by high percentages of reactive forms of sedimentary phosphorus. Negative benthic fluxes were associated with stations receiving more anthropogenic matter, which showed progressively decreasing phosphate concentrations in the interstitial water with depth. In these anthropogenic areas, the non-reactive forms of phosphorus (those associated with ferric oxyhydroxide and authigenic carbonate fluorapatite) are abundant, and reach values exceeding $75 \%$ of total phosphorus in sediment.
\end{abstract}

Keyworks: benthic fluxes, diffusive fluxes, phosphorus, sediment, Gulf of Cadiz, sequential extraction.

RESUMEN: ACUMULACIÓN DE FÓSFORO EN SEDIMENTOS MARINOS COSTEROS: RELACIÓN CON FLUJOS BENTÓNICOS Y DIFUSIVOS. - Se ha realizado la caracterización del fósforo sedimentario en 3 ecosistemas costeros del Golfo de Cádiz. Se ha encontrado una alta variabilidad espacial (desde 445 hasta $20291 \mu \mathrm{g} \mathrm{g.sed-1)} \mathrm{en} \mathrm{la} \mathrm{cantidad} \mathrm{de} \mathrm{fósforo} \mathrm{total,} \mathrm{y} \mathrm{en} \mathrm{las}$ otras fases de fósforo estudiadas. Esta variabilidad se correlaciona con la proximidad de las 10 estaciones de muestreo a las fuentes de efluentes urbanos e industriales de la zona. Los flujos difusivos y bentónicos fueron también medidos en las mismas estaciones de forma simultánea. Los valores de los flujos bentónicos están comprendidos entre -14 y $6 \mathrm{mmol} \mathrm{m}^{-2}$ $\mathrm{d}^{-1}$. Generalmente, un incremento de la concentración de fosfato en el agua intersticial con la profundidad se notó en aquellas zonas en las que se encontraron valores positivos de los flujos y que presentan altos porcentajes de las formas reactivas de fósforo en el sedimento. Por otra parte, los flujos bentónicos negativos parecen estar asociados a las estaciones que reciben más material de origen antropogénico y están relacionados con la disminución progresiva de las concentraciones de fosfato en el agua intersticial. En esas áreas antropogénicas, las formas no reactivas del fósforo (asociadas a oxihidróxidos de hierro y a carbonato fluorapatito autigénico) son las más abundantes, y llegan a alcanzar valores que superan el $75 \%$ del fósforo total del sedimento.

Palabras clave: flujos bentónicos, flujos difusivos, fósforo, sedimento, Golfo de Cádiz, extracción secuencial.

\section{INTRODUCTION}

Being an essential nutrient, phosphorus is a key element in biogeochemical cycles, and is believed to act as a limit to marine productivity (Berner et al., 1993; Ruttenberg, 1993). An important characteristic of phosphorus is that it can be transferred from seawater to the sediment. Hence, sedimentary phosphorus has been the subject of a number of studies, mainly because of its role in the eutrophication of marine and freshwaters.

Phosphorus is deposited in sediments in several ways: through incorporation in organic matter, through inclusion in apatite and calcium carbonate minerals, and through association with hydrous ferric oxides (Berner $e t$ 
al., 1993; McManus et al., 1997; Delaney, 1998). Once incorporated into the sediment, phosphorus also undergoes transformations itself, determined by the physicochemical characteristics of the sediment (Sundy et al., 1992; Lucotte et al., 1994; Louchouarn et al., 1997).

As a result of biological and chemical processes in the surface sediment, a certain amount of phosphorus is released from sediments and becomes available for biota (Pardo et al., 1999). Benthic regeneration of phosphate is a fundamental process in the exchange across the water-sediment interface. Therefore, it is important to study in situ fluxes and the phosphate chemistry in the interstitial water.

This study was performed in three different systems of the Gulf of Cadiz in the southern Iberian Peninsula, which is known to be affected to varying degrees by urban and/or industrial contamination. The first system, the Tinto and Odiel marshes, are formed at the intersection of the mouth of the rivers of the same name. These marshes are particularly important among the tidal marshes of the south coast of the Iberian Peninsula and have a high level of environmental protection. However, human activity interferes with the conservation of this ecosystem. A nearby petrochemical complex causes serious industrial pollution, and the system is also affected by other urban, agricultural and industrial discharges. Much research has been done on this area, but most studies have dealt with heavy metals and other pollutants (Saenz, 1998) and little attention has been paid to the exchange of nutrients between the sediment and the column water and its relation to sediment composition.

The second system, the Bay of Cadiz, is a shallow sea bay with an intertidal zone and an extensive salt marshes. The current problem of this system focuses on the large population concentrated in the zone, which carries with it other problems such as contaminant accumulation. Much research has been done on this area, primarily focusing on the diagenesis of organic matter in sediments and on benthic fluxes (Gómez-Parra and Forja, 1992; Forja and Gómez-Parra, 1998), but not on the characterization of the speciation of phosphorus in reactive phases in sediment.

Finally, the River Palmones estuary forms a marsh at the mouth, which is one of the few remaining wetlands in the Algeciras Bay. This system is characterized by waste and discharges it receives from industrial activity and adjacent urban areas. A number of studies of this system have characterized the amount and forms of the phosphorus in sediment and the phosphorus chemistry in the pore water (Clavero et al., 1991, Clavero et al., 2000), but have not dealt with the quantification of in situ benthic fluxes.

Therefore, the objective of the present study was to characterize and quantify the amount and distribution of phosphorus in coastal marine sediments and to determine how the phosphorus cycle near the sedimentwater interface affects the phosphate flux to overlying water.

\section{MATERIALS AND METHODS}

\section{Location of sampling stations}

The 10 stations are located in three different areas of the Gulf of Cadiz (Fig. 1). The Tinto and Odiel marshes (stations HA, HB, HC, HD) are very close to a major urban and industrial complex. The stations of the Bay of Cádiz (PR, G) are close to two medium-size towns. Finally, the River Palmones stations (PA PB, PC, PD) are located along the estuary. In general, all stations are primarily marine in nature. Samples were taken in winter and autumn 1998.

Two factors were considered in choosing these locations: i) sediment composition (texture, organic matter content, etc.), and ii) exposure to different degrees and types of pollution (Table 1).

\section{Benthic chambers}

Two opaque benthic chambers anchored at each station for 4 hours were used to study benthic fluxes of phosphate. The volume capacity of the chambers was 78.3 and $89.8 \mathrm{~L}$, and both had the same cross-sectional area of $0.385 \mathrm{~m}^{2}$. The chambers had their own

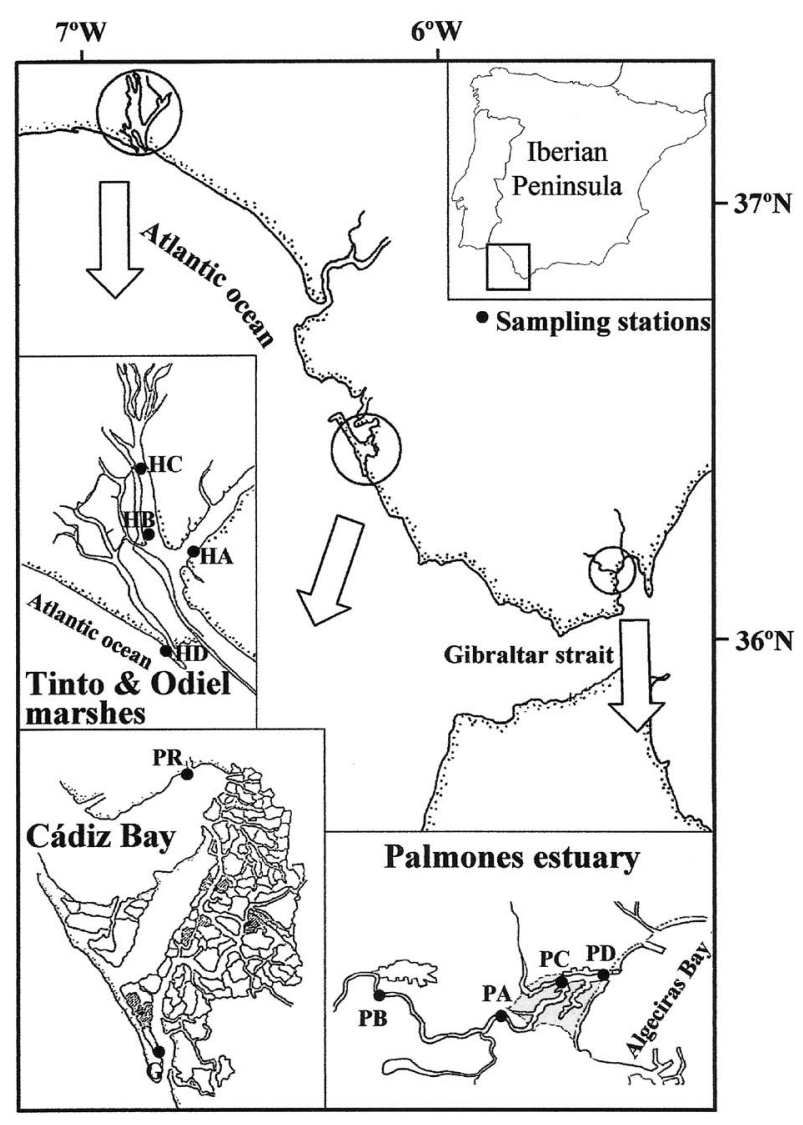

FIG. 1. - Map of Gulf of Cadiz showing location of the sampling stations in the three different study areas: Tinto and Odiel marshes, Bay of Cadiz and Palmones estuary. 
TABLE 1. - Characterization of the 10 sampling stations in the Gulf of Cadiz.

\begin{tabular}{|c|c|c|c|c|c|c|}
\hline & Date & Station & Type of Sediment & Anthropogenic influence & Vater temperature $\left({ }^{\circ} \mathrm{C}\right)$ & Salinity \\
\hline \multirow[t]{4}{*}{ Tinto and Odiel marshes } & \multirow[t]{4}{*}{ Sept/98 } & HA & clayey silt & high industrial effluents & 24.0 & 37.5 \\
\hline & & HB & sandy silt & high industrial effluents & 22.1 & 36.2 \\
\hline & & $\mathrm{HC}$ & clayey silt & high industrial effluents & 24.0 & 38.1 \\
\hline & & HD & sand & high industrial effluents & 20.0 & 36.4 \\
\hline \multirow[t]{2}{*}{ Bay of Cadiz } & \multirow[t]{2}{*}{ Nov/98 } & PR & silty sand & moderate urban effluents & 18.3 & 36.7 \\
\hline & & $\mathrm{G}$ & silty clay & moderate urban and industrial effluents & 17.8 & 37.0 \\
\hline \multirow[t]{4}{*}{ Palmones estuary } & \multirow[t]{4}{*}{ Jan/98 } & PA & silty clay & moderated urban and industrial effluents & 15.8 & 23.6 \\
\hline & & PB & silty sand & semi-closed and degraded system & 13.5 & 9.5 \\
\hline & & $\mathrm{PC}$ & clayey silt & low urban effluents & 15.4 & 36.4 \\
\hline & & PD & clayey silt & low urban effluents & 15.6 & 35.8 \\
\hline
\end{tabular}

A

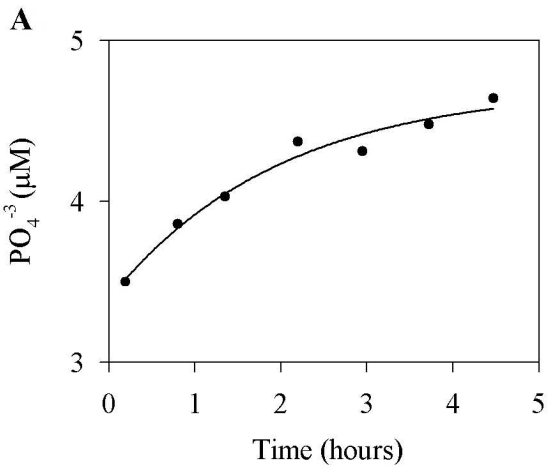

C
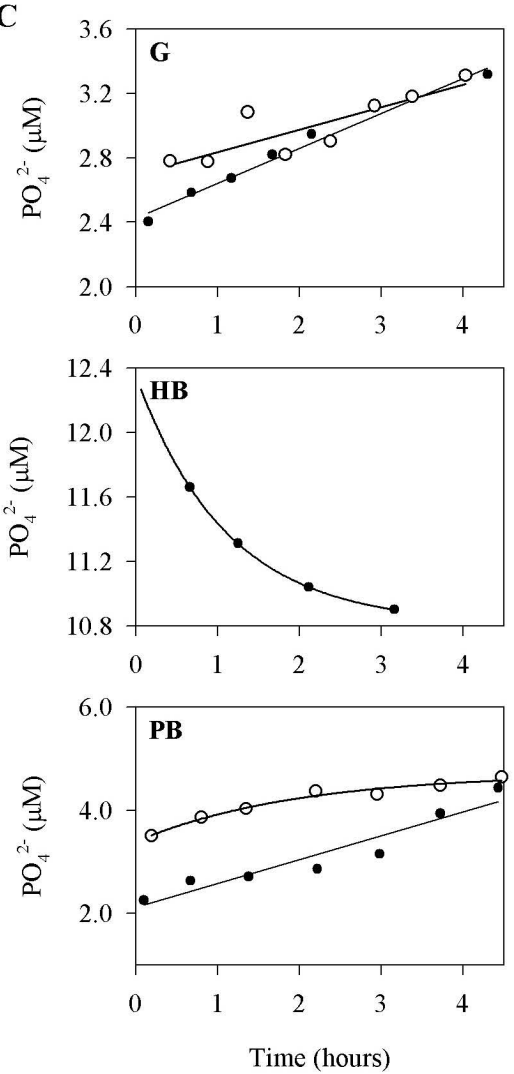

$\mathrm{PO}_{4}^{-3}(\mu \mathrm{M})$
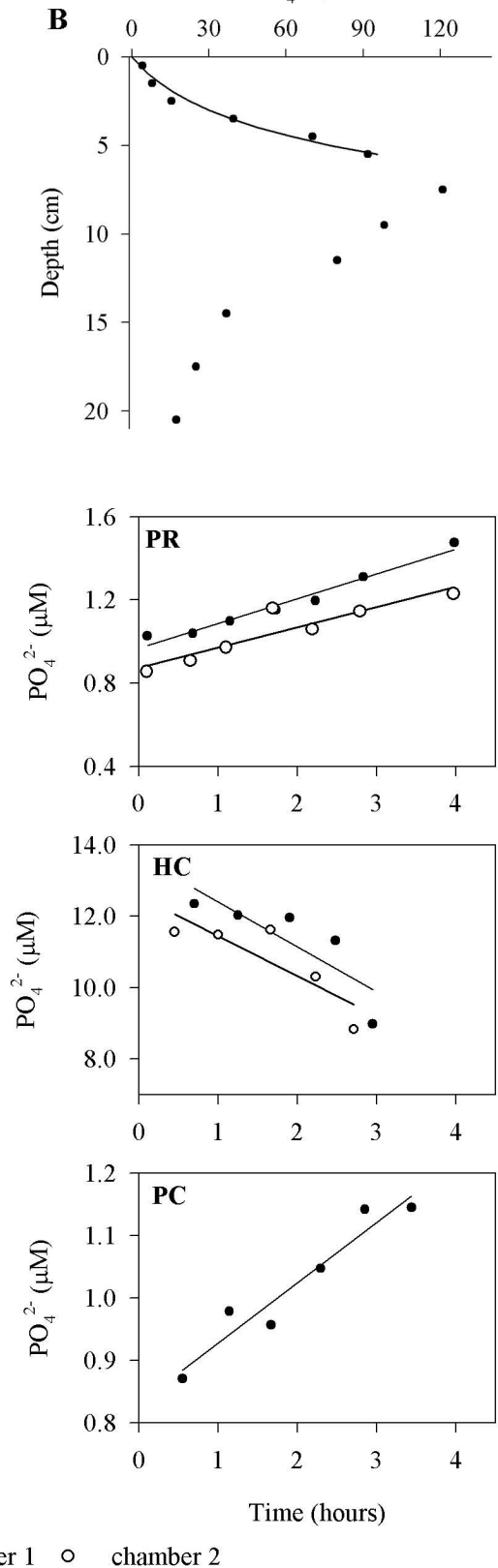

FIG. 2. - Variations in phosphate concentration inside the benthic chamber (A) and in the interstitial water (B) at station PB. (C) Variations in phosphate concentration inside the benthic chambers at two stations for each system studied. Exponential/linear fits used for the calculation of the benthic and diffusive fluxes have been superimposed on the experimental data. 
agitation system (variable-speed recirculation pump), and samples were taken every 30 minutes. A detailed description of the chambers and their method of operation is given in Gómez-Parra and Forja (1993).

The in situ benthic fluxes were calculated using the following expression:

$$
\mathrm{J}_{\mathrm{S}}=\mathrm{R}^{-1} \cdot(\partial \mathrm{C} / \partial \mathrm{t})_{\mathrm{t}=0}
$$

where $\mathrm{R}$ is the surface-to-volume ratio in the chamber (4.98 and $4.29 \mathrm{~m}^{-1}$, respectively), and $(\partial \mathrm{C} / \partial \mathrm{t})_{\mathrm{t}=0}$ is calculated from the variations in phosphate concentration inside the chambers. These variations in $\mathrm{C}$ with time may be described by means of either a linear or an exponential equation; the latter is shown in Figure 2.

\section{Sediment}

At each station, 3 or 4 sediment cores (inner diameter $60 \mathrm{~mm}$ ) were collected by scuba diving, and were immediately frozen and preserved at $-20^{\circ} \mathrm{C}$ until subsequent laboratory treatment. From each core, sections of $1-\mathrm{cm}$ thickness were cut at various depths under $\mathrm{N}_{2}$ atmosphere; these sections were then centrifuged (39200 g/30 min) in polypropylene tubes to obtain the interstitial water. The phosphate concentration in interstitial water was determined by the spectrophotometric method (Grasshoff et al., 1983) using an autoanalyser (Traccs 800, Bran-Luebbe).

The sediment was dried at $85^{\circ} \mathrm{C}$ for 48 hours, then ground with a $\mathrm{ZrO}_{2}$ grinder and sieved $(63 \mu \mathrm{m})$. The organic carbon content of surface sediment (0-10 $\mathrm{cm}$ depth) was measured using a chemical oxidation method (El Rayis, 1985). Sediment porosity was calculated by determining the weight loss after drying for 48 hours at $85^{\circ} \mathrm{C}$.

Sediment samples to determine sediment grain size were taken using a Van Veen grab. In the thick fraction, the separation by grain size was performed using a stack of sieves, and the fine fraction distribution was determined using a laser particle analyzer (FRITSCH, mod. Analysette 22). The texture of the sediment samples was classified using Shepard's system (Shepard, 1954).

\section{Diffusive fluxes}

Diffusive fluxes across the sediment-water interface were estimated using Fick's first law (Berner, 1976):

$$
\mathrm{J}_{\mathrm{D}}= \pm \phi_{0} \cdot \mathrm{D}_{\mathrm{S}} \cdot(\partial \mathrm{C} / \partial \mathrm{z})_{\mathrm{z}=0}
$$

where $\mathrm{J}_{\mathrm{D}}$ is the specie's flux across the sediment-water interface, $\phi_{0}$ is the porosity of surface sediment, $D_{S}$ is the molecular diffusion coefficient, and $(\partial \mathrm{C} / \partial \mathrm{z})_{\mathrm{z}=0}$ is the concentration gradient across the water-sediment interface calculated from linear or exponential fitting of phosphate against depth for the surface layer of the sediment (first few centimetres).
An example of exponential fitting is shown for station PB (Fig. 3B). The porosity variations with depth were fitted to an exponential expression (Morse, 1974; Lerman, 1976; Murray et al., 1978) such that:

$$
\phi=\phi_{\mathrm{z}}+\left(\phi_{0}-\phi_{\mathrm{z}}\right) \mathrm{e}^{-\mathrm{az}}
$$

in which $\phi_{z}$ is the analytical porosity asymptote and $\phi_{0}$ its value at $\mathrm{z}=0$. The diffusion coefficient $\mathrm{D}_{\mathrm{S}}$ in the surface layers was calculated using the expression reported by Sweerts et al. (1991). This equation allows $\mathrm{D}_{\mathrm{S}}$ to be related directly to porosity:

$$
\mathrm{D}_{\mathrm{s}}=\mathrm{D}^{0} \cdot(-0.73 \cdot \phi+2.17)^{-1}
$$

where $\mathrm{D}^{0}$ is the diffusion coefficient at infinite dilution. In the case of phosphate, the effective diffusion coefficient $\left(\mathrm{D}_{\text {eff }}\right)$ is utilized in place of $\mathrm{D}^{0}$ (Klump and Martens, 1981), and this coefficient was calculated by the following expression:

$$
\mathrm{D}_{\text {eff }}=\Sigma \alpha_{\mathrm{i}} \cdot \mathrm{D}_{\mathrm{i}}
$$

where $\alpha_{i}$ is the relative proportion of each phosphoric acid equilibrium species, and $D_{i}$ is the diffusion coefficient at infinite dilution $\left(\mathrm{D}^{0}\right)$ of each species involved (Krom and Berner, 1980) (Table 2).

This effective coefficient is calculated from the relative proportions of each species including the formation of ionic pairs with the majority cations in seawater. The relative proportions were determined with the apparent dissociation constants reported in DOE (1994) and the stability constants of different ion pairs described by Turner et al. (1981).

The considerations and simplifications described by Klump and Martens (1981) were applied. These authors found errors of up to $50 \%$ when the phosphoric acid speciation was not considered in the $\mathrm{D}_{\mathrm{S}}$ calculation, as a consequence of $\mathrm{pH}$ variation in interstitial water.

\section{Sequential extraction of phosphorus in sediment}

The detailed protocol for obtaining the different phosphorus fractions is illustrated schematically in Table 3. The extraction method used was the modified Williams's protocol (Williams, 1980 in Ruban et al., 1999). We performed one prior step, which consisted of the initial extraction using the Ruttenberg method (Ruttenberg, 1992). This extraction using $1 \mathrm{M} \mathrm{MgCl}_{2}$ extracts the loosely-sorbed phosphorus (F1), which is

TABLE 2. - Diffusion coefficient at infinite dilution $\left(\mathrm{D}^{0}\right)$ of each species of phosphoric acid equilibrium and applied species

\begin{tabular}{lll}
\hline & $\mathrm{D}^{0}\left(10^{-6} \mathrm{~cm}^{2} \cdot \mathrm{s}^{-1}\right)\left(\mathrm{t}\right.$ in $\left.{ }^{\circ} \mathrm{C}\right)$ & Applied species \\
\hline $\mathrm{H}_{2} \mathrm{PO}_{4}^{-}$ & $=8.46+0.19 \cdot(\mathrm{t}-25)$ & $\mathrm{H}_{2} \mathrm{PO}_{4}^{-}, \mathrm{NaHPO}_{4}^{-}, \mathrm{KHPO}_{4}^{-}$, \\
$\mathrm{MPO}_{4}{ }^{2-}$ & $=7.34+0.16 \cdot(\mathrm{t}-25)$ & $\mathrm{MPO}_{4}{ }^{2-}$, \\
$\mathrm{PO}_{4}^{3-}$ & $=6.12+0.133 \mathrm{j} 2 \cdot(\mathrm{t}-25)$ & $\mathrm{PO}_{4}^{3-}$ free \\
$\mathrm{Neutral}^{-}$ & $=14+0.3044 \cdot(\mathrm{t}-25)$ & $\mathrm{MgHPO}_{4}{ }^{0}, \mathrm{CaHPO}_{4}{ }^{0}$ \\
\hline
\end{tabular}



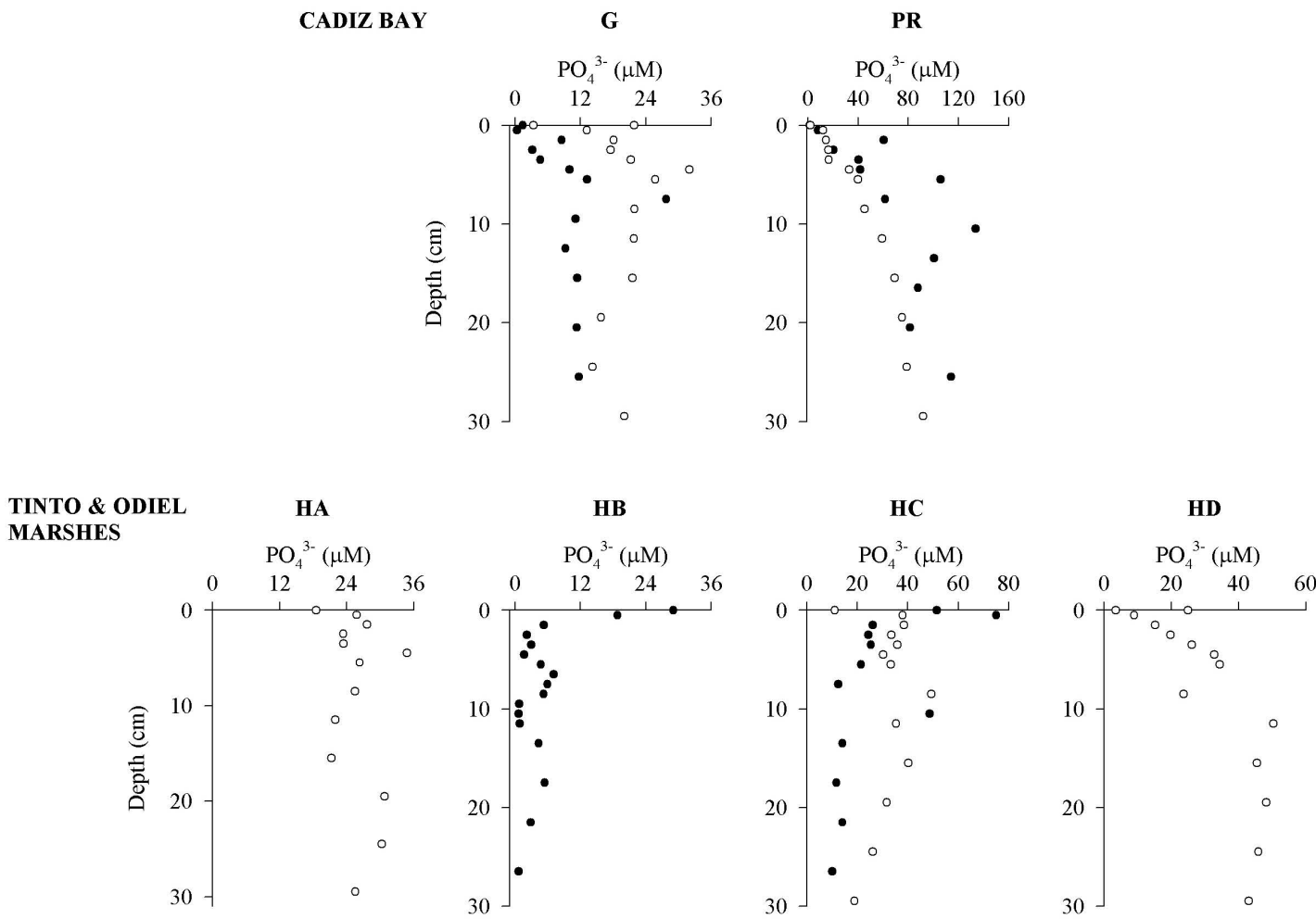

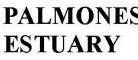
ESTUARY

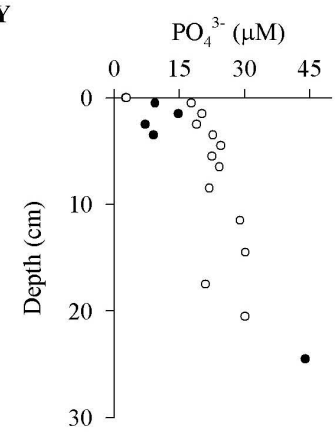

PB

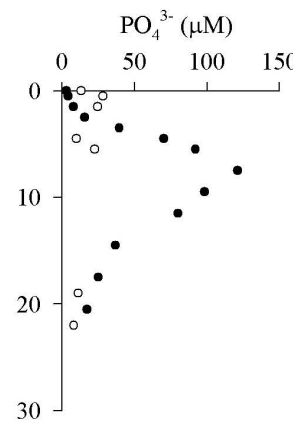

PC

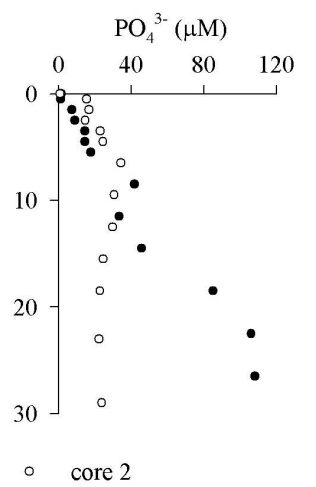

PD

$\mathrm{PO}_{4}^{3-}(\mu \mathrm{M})$

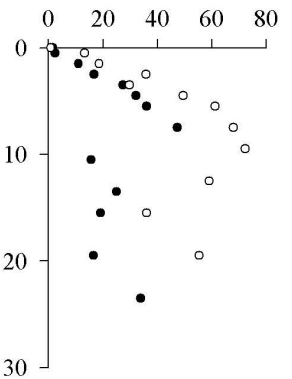

FIG. 3. - Vertical profiles of phosphate (in $\mu \mathrm{M}$ ) in interstitial water at each station.

the more labile form of sedimentary phosphorus. From the remaining residue, the iron-bound or non-apatite inorganic phosphorus (NAIP, F2) was extracted using $1 \mathrm{M} \mathrm{NaOH}$ and subsequent neutralization with $3.5 \mathrm{M}$ $\mathrm{HCl}$. The extraction of the various different forms of phosphorus continued, following the procedure described in Ruban et al. (1999) (Table 3).

In all cases the extractions were performed from 0.5 $\mathrm{g}$ of sediment in $50 \mathrm{~mL}$ of extractant for 16 hours at room temperature, with agitation and in polypropylene tubes. In each extraction, centrifugation at $15000 \mathrm{~g}$ for 15 minutes at $4^{\circ} \mathrm{C}$ was used to separate the liquid and solid phases. The phosphate concentration in each extractant was determined using the spectrophotometric method (Koroleff, 1983), with prior dilution where necessary and adjustment to $\mathrm{pH}$ of about 1 .
RESULTS

\section{Phosphate profiles}

Depth profiles of phosphate in the interstitial water at the stations studied are shown in Figure 3. These profiles can be seen to be very irregular at some stations, as a consequence of organic matter remineralization and subsequent phosphate removal from interstitial water due to authigenic mineral formation.

Many profiles showed a constant increase in phosphate concentration with depth, from values close to 0 $\mu \mathrm{M}$ to values exceeding $120 \mu \mathrm{M}$, as in the case of the $\mathrm{PR}$ and PC stations. One group of stations (G, PB, PD) showed increased phosphate from the superficial part of the sediment to a certain depth, from which there 
TABLE 3. - Reagent characteristics and corresponding $\mathrm{P}$ fractions in the sequential extraction method applied to three splits of sediment (A, $\mathrm{B}, \mathrm{C})$.

\begin{tabular}{|c|c|c|c|c|}
\hline & Fraction & Reagent & Extracted form of $\mathrm{P}$ & Reaction \\
\hline \multirow[t]{3}{*}{ A } & Labile P (F1) & $\mathrm{MgCl}_{2}(1 \mathrm{M}, \mathrm{pH} 8)$ & $\begin{array}{l}\text { Labile and loosely sorbed P. } \\
\text { Bioavailable. }\end{array}$ & $\begin{array}{l}\text { Complex formation of } \mathrm{MgPO}_{4}^{-} \\
\text {and/or displacement by } \mathrm{Cl}^{-} \text {. }\end{array}$ \\
\hline & NAIP (F2) & $\mathrm{NaOH}(1 \mathrm{M})$ & $\begin{array}{l}\text { Easily reducible or linked to } \mathrm{Fe}, \mathrm{Al}, \mathrm{Mn} \text {. } \\
\text { Non-apatite inorganic P. Bioavailable. }\end{array}$ & Metal solubilization \\
\hline & AIP (F3) & $\mathrm{HCl}(1 \mathrm{M})$ & Apatitic inorganic P. Non-bioavailable. & Acid dissolution \\
\hline B & $\begin{array}{l}\text { IP (F4) } \\
\text { OP (F5) }\end{array}$ & $\begin{array}{c}\mathrm{HCl}(1 \mathrm{M}) \\
\text { Ashing }\left(450^{\circ} \mathrm{C}\right)+\mathrm{HCl}(1 \mathrm{M})\end{array}$ & $\begin{array}{l}\text { Inorganic P } \\
\text { Organic P. Partly bioavailable. }\end{array}$ & $\begin{array}{l}\text { Acid dissolution } \\
\text { Dry oxidation at } 450^{\circ} \mathrm{C} \text { and acid } \\
\text { extraction of ashed residue }\end{array}$ \\
\hline $\mathrm{C}$ & $\mathrm{TP}$ & Ashing $\left(450^{\circ} \mathrm{C}\right)+\mathrm{HCl}(3.5 \mathrm{M})$ & Total P & $\begin{array}{l}\text { Dry oxidation at } 450^{\circ} \mathrm{C} \text { and acid } \\
\text { extraction of ashed residue }\end{array}$ \\
\hline
\end{tabular}

TABLE 4. - The porosity of surface sediment $\left(\phi_{0}\right)$, diffusion coefficient $\left(\mathrm{D}_{\mathrm{S}}\right)$ and diffusive fluxes $\left(\mathrm{J}_{\mathrm{D}}\right)$, at each station. Corresponding organic carbon (OC) and total phosphorus (TP) contents of surface sediment are also shown.

\begin{tabular}{lcccccc}
\hline & Station & $\phi_{0}$ & $\begin{array}{c}\mathrm{D}_{\mathrm{S}} \cdot 10^{6} \\
\left(\mathrm{~cm}^{2} \mathrm{~s}^{-1}\right)\end{array}$ & $\begin{array}{c}\mathrm{J}_{\mathrm{D}} \\
\left(\mathrm{mmol} \mathrm{m}^{-2} \mathrm{~d}^{-1}\right)\end{array}$ & $\begin{array}{c}\text { OC } \\
(\%)\end{array}$ & $\begin{array}{c}\mathrm{TP} \\
(\mu \mathrm{g} \mathrm{g.sed})\end{array}$ \\
\hline Tinto and Odiel marshes & HA & 0.551 & 3.96 & -0.0007 & $2.40 \pm 0.17$ & $20291 \pm 3495$ \\
& HB & -- & -- & -- & 2.08 & 6055 \\
& HC & 0.475 & 3.84 & -0.0021 & $2.26 \pm 0.12$ & $13430 \pm 963$ \\
Bay of Cadiz & HD & 0.420 & 3.76 & 0.0148 & $1.11 \pm 0.22$ & $2307 \pm 929$ \\
& PR & 0.636 & 4.10 & 0.0089 & $2.57 \pm 0.20$ & $1036 \pm 92$ \\
Palmones estuary & G & 0.731 & 4.28 & 0.0112 & $1.46 \pm 0.03$ & $1084 \pm 48$ \\
& PA & 0.654 & 4.13 & -0.0173 & $1.74 \pm 1.12$ & $455 \pm 452$ \\
& PB & 0.581 & 4.01 & 0.0112 & $1.85 \pm 0.24$ & $445 \pm 67$ \\
& PC & 0.755 & 4.32 & 0.0138 & $2.38 \pm 0.33$ & $814 \pm 96$ \\
& PD & 0.661 & 4.15 & 0.0154 & $2.91 \pm 0.20$ & $867 \pm 74$ \\
\hline
\end{tabular}

was a negative gradient change. Finally, another group showed a significant decrease in phosphate concentration in interstitial water, as in the case of station HB.

\section{Diffusive and benthic fluxes}

Porosity values, the diffusion coefficient $D_{S}$ and the results for diffusive fluxes are summarized in Table 4. In all cases, the values of phosphate diffusive fluxes were relatively small, in the order of $\mu \mathrm{mol} \mathrm{m} \mathrm{m}^{-2} \mathrm{~d}^{-1}$. Most stations showed positive values of phosphate diffusive fluxes, indicating that there was release of phosphate from the sediment into the water column, with values between 0.0089 and $0.0154 \mathrm{mmol} \mathrm{m}^{-2} \mathrm{~d}^{-1}$. However, stations HA, HC and PA showed negative phosphate diffusive fluxes.

The values of the phosphate benthic fluxes were between -14 and $6 \mathrm{mmol} \mathrm{m}^{-2} \mathrm{~d}^{-1}$ (Fig. 4). The inner stations of the Tinto and Odiel marshes showed the greatest removal of phosphate into the sediment, while the highest fluxes from sediment to the water column were found at station HD. The other stations showed much lower values, ranging between -2 and $2 \mathrm{mmol} \mathrm{m}^{-2} \mathrm{~d}^{-1}$.

\section{Sedimentary phosphorus}

Two examples of depth profiles of variations in the fractions of phosphorus in the sediment are shown in Figure 5. The general trend found was a progressive decrease in total phosphorus (TP) and all forms of $\mathrm{P}$ in the sediment, as seen in the profile of station PA. This type of profile was found at the stations of the Bay of Cadiz and the Palmones estuary.

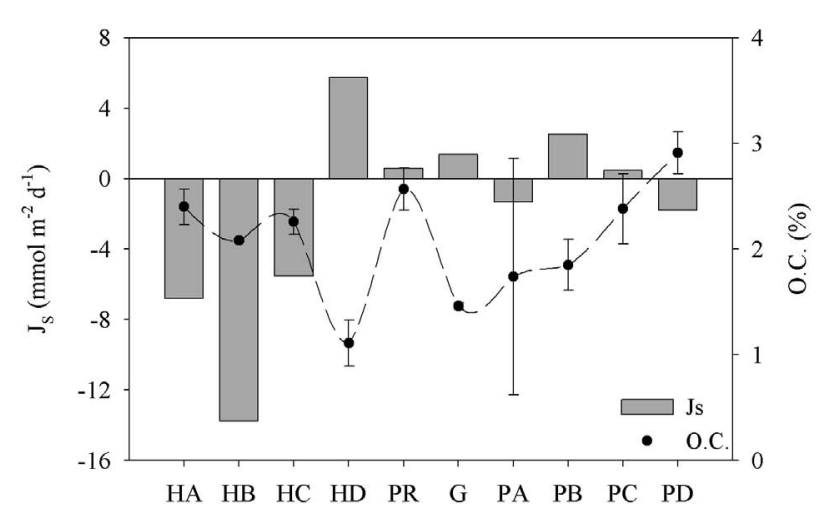

FIG. 4. - Benthic fluxes of phosphate $\left(\mathrm{J}_{\mathrm{S}}\right)$ and organic carbon content (OC) in surface sediment at each station.

The profile of station HD showed a progressive increase in both TP and fractions. The TP in deep sedi-

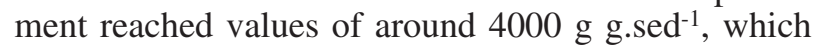
is up to four times higher than surface values. Stations $\mathrm{HA}$ and $\mathrm{HC}$ have the same type of profile.

Figure 6 shows the overall average depths between 0 and $10 \mathrm{~cm}$ of different fractions of phosphorus in sediment in relation to TP at each of the 10 stations. The greatest fraction was inorganic $\mathrm{P}$, especially at the stations of the Tinto and Odiel marshes, while organic $\mathrm{P}$ values only reached $20-30 \%$ at the stations of the Bay of Cadiz and the Palmones estuary.

The fraction of inorganic P bound to Fe (F2) represents the majority fraction in the Tinto and Odiel marsh stations. However, in the rest of the stations the fraction of $\mathrm{P}$ associated with $\mathrm{Ca}(\mathrm{F} 3)$ had a greater relative importance, although the two fractions showed similar percent- 


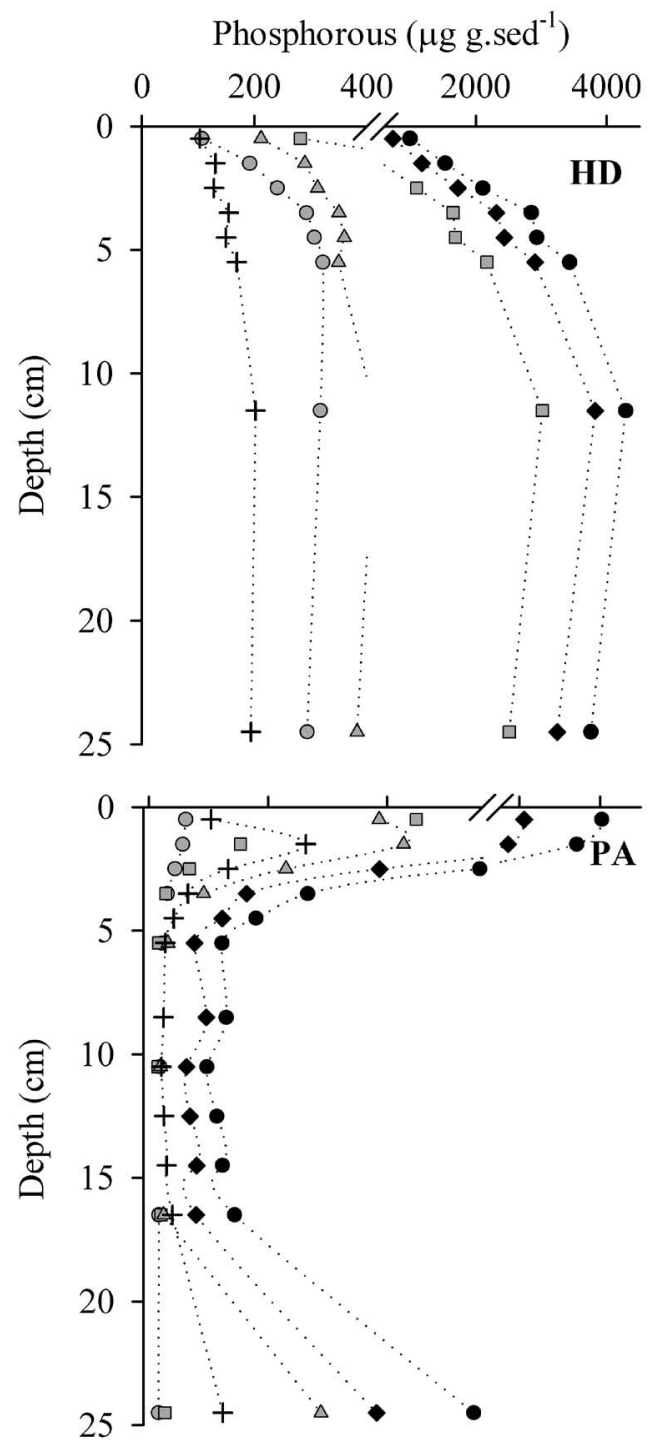

FIG. 5. - Examples of sediment profiles of the different fractions of phosphorus at stations HD and PA.

ages. At all stations studied, labile P (F1) was the minority faction, representing between $3 \%$ and $10 \%$ of TP.

\section{DISCUSSION}

\section{Phosphate chemistry in interstitial water}

In most cases, an increase in the concentration of phosphate with depth can be observed, with some values reaching more than $100 \mu \mathrm{M} \mathrm{PO}_{4}$ (Fig. 3). This behaviour has been described in numerous littoral systems (e.g., Sundy et al., 1992; McManus et al., 1997) and is generally found to be related to the release of phosphorus from organic matter during diagenesis in the first few centimetres of sediment. Mineralization of organic material also produces significant changes in the redox potential and $\mathrm{pH}$ of the interstitial water, and may induce a release from the phosphorus of the
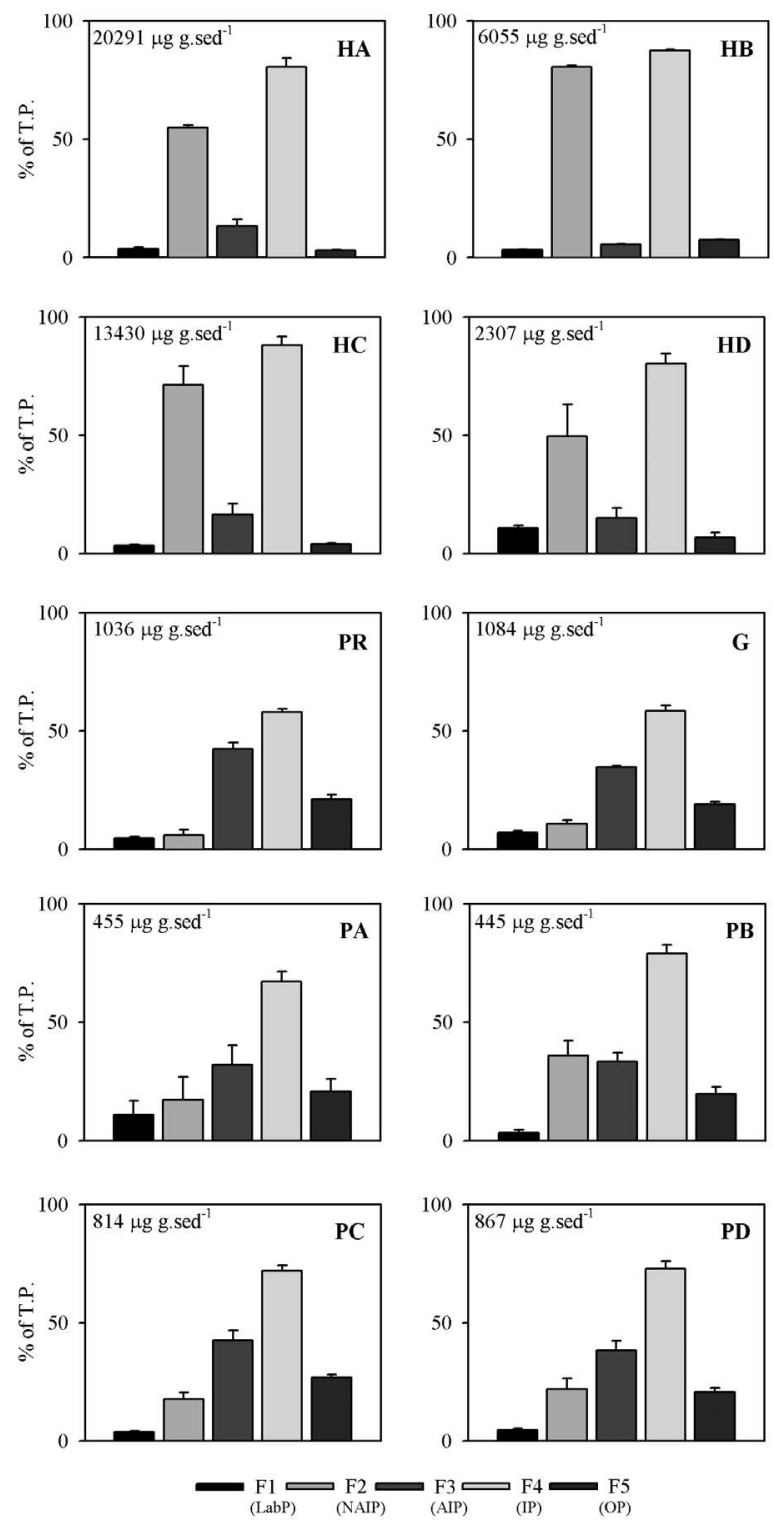

FIG. 6. - Distribution of different phases of phosphorus in surface sediment $(0-10 \mathrm{~cm})$ (total phosphorus, shown in upper left corner).

more reactive phases (Sundy et al., 1992; Istvanovics and Pettersson, 1998).

At some stations (for example $\mathrm{HB}$ and $\mathrm{HC}$ ) phosphate removal was observed at different depths due to processes such as the formation of $\mathrm{Fe}$ and/or $\mathrm{Ca}$ authigenic insoluble compounds (Sundby et al., 1992; Barbanti et al., 1995).

\section{Diffusive and benthic fluxes}

In all cases, the values of phosphate diffusive fluxes observed in different systems studied were of the same order of magnitude as those observed in various shallow and deep systems (Table 5). The values found for diffusive fluxes were very low in comparison with 
TABLE 5. - Comparison of phosphate diffusive fluxes in this study with other systems reported.

\begin{tabular}{lcc}
\hline System & $\mathrm{J}_{\mathrm{d}}\left(\mathrm{mmol} \mathrm{m}^{-2} \mathrm{~d}^{-1}\right)$ & Reference \\
\hline Narragansett Bay & 0.007 & McCaffrey et al. (1980) \\
Great Bay & 0.043 & Lyons et al. $(1982)$ \\
Northern Adriatic Sea & $0.0001-0.0020$ & Giordani and Hammond (1985) \\
San Francisco Bay & $0.00-0.52$ & Hammond et al. $(1985)$ \\
Palmones estuary & $0.007-0.156$ & Clavero et al. $(1991)$ \\
Northern Adriatic Sea & $0.007-0.260$ & Barbanti et al. $(1995)$ \\
Albufera of Majorca & 0.332 & López et al. $(1995)$ \\
Tuamotu Archipelago & $0.0006-0.0103$ & Charpy-Roubaud et al. $(1996)$ \\
Palmones estuary & $0.030-0.067$ & Clavero et al. $(2000)$ \\
Various marine systems & $0.0356-0.960$ & Colman and Holland (2000) \\
Arabian Sea & $0.0109-0.0510$ & Grandel et al (2000) \\
Eastern north Atlantic & 0.0008 & Black et al. $(2001)$ \\
Bay of Cádiz & $0.0187-0.0721$ & This study \\
Tinto and Odiel marshes & $-0.0642-0.0139$ & This study \\
Palmones estuary & $0.0096-0.1760$ & This study \\
\hline
\end{tabular}

benthic fluxes in all cases (Table 4, Fig. 4). This underestimation of the diffusive fluxes was obtained using a spatial resolution in vertical profiles of $1 \mathrm{~cm}$, and confirms the importance of macrofaunal irrigation in the exchange of nutrients between sediment and overlying water (e.g. Aller, 1978; Callender and Hammond, 1982; Doering et al., 1987; Clavero et al., 1991; Forja and Gómez-Parra, 1998).

In most cases, the positive values of phosphate diffusive fluxes indicate that this nutrient is released during organic matter diagenesis and is exported from sediment to the water column (Table 4). Phosphate removed by sediment was only detected at the inner stations of the Tinto and Odiel river mouths (sampling stations HA and HC). On the other hand, a progressive increase of phosphate diffusive fluxes was found in the Palmones estuary.

Benthic fluxes of phosphate (Fig. 4) show great spatial variability. The highest negative values of benthic fluxes in water were found at stations $\mathrm{HA}, \mathrm{HB}$ and $\mathrm{HC}$, where the highest TP values in sediment were found, indicating that sediments act as a sink of P from the water column in this zone.

These stations are subjected to severe contamination by industrial effluents containing high concentrations of phosphate, iron and other heavy metals, giving rise to a substantial transfer of phosphate from water to sediment, which then forms part of the sediment. In fact, the initial concentrations of phosphate inside the chambers reach values of $24 \mu \mathrm{M} \mathrm{PO}_{4}$ at station $\mathrm{HB}$, and a gradual decrease in the concentration is observed in line with increasing time of incubation. In general, there is no clear dependence between the phosphate fluxes and the organic carbon content of the surface sediments (Fig. 4). Hence, the release of phosphate from the sediment may be more related to the degree of degradation of the organic material than to its total quantity (Forja et al., 1994).

\section{Different fractions of phosphorus}

The stations studied show considerable variability in the total amount of phosphorus in sediment and in the distribution of the different phases of phosphorus. The highest TP values were found at the stations in the Tinto and Odiel marshes, sited near a major industrial complex (Table 4). In contrast, stations PA and PB in the Palmones estuary showed the lowest TP and organic carbon values. These variations could be due fundamentally to the degree and nature of the effluent sources located near the stations.

Figure 5 shows that there is a significant difference between stations HD and PA in both the absolute values and the distribution of the different fractions of phosphorus. Station HD receives considerable quantities of matter of anthropogenic origin containing both phosphate and various heavy metals such as iron. At this station, it is notable that the inorganic fraction, and F2 (NAIP) specifically, is proportionately the greatest, due to the characteristics of the zone in which the values of Fe in the sediment can reach as much as $150 \mathrm{mg}$ g.sed ${ }^{-1}$ (Sáenz, 1998). It can also be seen in this profile that there is a generalized increase in phosphorus with sediment depth, which could be related to the smaller amounts of anthropogenic matter received by this zone in recent years. All stations in the Odiel-Tinto marshes show this pattern.

The tendency found at station PA is very different, and appears more similar to the usual pattern of distribution of phases of phosphorus (e.g.: Berner et al., 1993). The accumulation of phosphorus occurs mainly in the surface sediment, since the sediment consists of more clay; another factor is the recent input of phosphorus in effluent from different industries located nearby at station PA. In both cases, inorganic phosphorus is the predominant pool, and thus drives the variation of TP. The two important parts of the mechanisms by which phosphate is removed from seawater are, first, its inclusion in carbonate fluorapatite and in biogenic calcium carbonate, and second, the adsorption of phosphate onto ferric oxyhydroxides (Berner et al., 1993).

In general, we found a decline in the absolute values and percentage of organic P (F5) in the sediment with depth, due to decomposition of organic matter during diagenesis. In many cases, organic P was reduced by half in the first $10 \mathrm{~cm}$ of sediment. 
TABLE 6. - Values of phosphorus fractions (in $\mu \mathrm{g} \mathrm{P} \mathrm{g.sed}{ }^{-1}$ ) found by other authors and in sediment in the zones studied.

\begin{tabular}{|c|c|c|c|c|c|c|}
\hline Zone & Total P & Labile P & NAIP & AIP & Organic P & Reference \\
\hline Medes Islands and Fangar Bay & $150-250$ & $0.08-0.39$ & -- & -- & -- & Vidal (1988) \\
\hline St. Lawrence Gulf, NY & 1625 & 34 & 694 & 793 & 105 & Sundby et al. (1992) \\
\hline American continental margin & $118.9-574.2$ & -- & -- & -- & $4.95-118.6$ & Ingall et al. (1993) \\
\hline Mississippi Delta & $586-605$ & $23-48$ & $141-182$ & 206-211 & 117-169 & Ruttenberg and Berner (1993) \\
\hline Long Island, NY & 436 & 35 & nd & 305 & 96 & Ruttenberg and Berner (1993) \\
\hline American continental margin & $715.5-1363$ & -- & -- & -- & $99.12-309.7$ & Ingall and Jahnke (1994) \\
\hline Florida coast & 54-1473 & $0.5-1.7$ & $15-554$ & $15-354$ & $24-527$ & Koch (1997) \\
\hline Tomales Bay, California & $654.2-952.1$ & $8.1-50.2$ & nd & $73.1-154.9$ & $158.3-475.8$ & Vink et al. (1997) \\
\hline Bermudas Islands & $82-168$ & $2.2-6.2$ & $14-28$ & $58-129$ & $2.2-4.6$ & Jensen et al. (1998) \\
\hline Tabor Lake, Canada & 84-208 & -- & $19-28$ & -- & -- & Petticrew and Arocena (2001) \\
\hline Alton Water Dam, UK & -- & $80-620$ & $460-3220$ & $460-3330$ & -- & Perkins and Underwood (2001) \\
\hline Florida Bay & $56-369$ & 0.1-19 & $<1.0-68$ & 34-151 & 20-70 & Koch et al. (2001) \\
\hline Bay of Cádiz & $1065 \pm 50.32$ & $66.23 \pm 22.21$ & $96.97 \pm 40.12$ & $416.1 \pm 47.95$ & $220.5 \pm 14.66$ & This work \\
\hline Tinto and Odiel marshes & $10760 \pm 7644$ & $408.0 \pm 236.7$ & $6743 \pm 4512$ & $1427 \pm 1287$ & $434.9 \pm 205.4$ & This work \\
\hline Palmones estuary & $675.5 \pm 232.5$ & $39.40 \pm 4.14$ & $161.0 \pm 34.20$ & $259.4 \pm 108.8$ & $159.6 \pm 68.81$ & This work \\
\hline
\end{tabular}

The stations of the Odiel salt marshes (HA to HD) showed very high percentages of F2 (NAIP) (Fig. 6). It is possible that the considerable supply of $\mathrm{Fe}$ in this zone from industrial effluents facilitates the incorporation of phosphorus into this phase, which can comprise as much as $92 \%$ of the total inorganic phosphorus.

At the rest of the stations, the fraction of inorganic phosphorus (F4) was also the most abundant one, although organic phosphorus (F5) showed values of around 20\% (Fig. 6). Among the inorganic phases, apatite (F3, AIP) was generally the most abundant. Table 6 shows that this apatite fraction is the most abundant in the most marine sediment.

In all cases, the most labile fraction of phosphorus (F1) is that which comprises the smallest percentage $(<15 \%)$. This finding could indicate that this fraction has a high reactivity in marine sediments. The distribution of the different fractions of phosphorus in the sediment is very similar to that found in the majority of the marine sediments (Table 6).

The TP values found in the Odiel salt marshes are 10 times higher than those in other systems (Table 6). This site could act as a large sink for phosphorus, since the benthic fluxes at this site are equivalent to those at other sites. Unlike at the stations of the Bay of Cadiz and the Palmones estuary, at the stations of the Tinto and Odiel marshes the most abundant fraction of inorganic phosphorus was NAIP (Fig. 6).

\section{CONCLUSIONS}

Benthic fluxes of phosphate are higher than diffusive fluxes, showing the importance of bioturbation processes on phosphate mobility at the sediment-water interface, as well as the importance of working with a high spatial resolution.

There is considerable variability among the stations studied in the total amount of phosphorus in sediment and in the distribution of the different phases of phosphorus. These variations are due fundamentally to the degree and the nature of the effluents discharged from sources of located near the stations.

The less reactive phases of phosphorus (F2 and F3) show the same pattern as the total amount of phosphorus in sediment. On the other hand, more labile phosphorus (F1) and organic phosphorus (F5) shows patterns more conditioned by the characteristics of the sediment and diagenetic processes of organic matter. In general, the percentages of phases F2 and F3 measured at stations with substantial anthropogenic inputs of phosphorus were higher than those found at stations with less industrial and urban contamination, in both surface sediment and deep sediment.

The stations with the highest TP values (Tinto and Odiel marshes) showed high negative values of benthic fluxes, indicating that sediments act as a sink of $\mathrm{P}$ from the water column.

\section{REFERENCES}

Aller, R.C. - 1978. The effects of animal-sediment interactions on geochemical processes near the sediment-water interface. In M.L. Wiley (ed.), Estuarine interactions. pp. 157-172. Academic Press, New York.

Barbanti, A., M.C. Bergamini, F. Frascari, S. Miserocchi, M. Ratta and G. Rosso. - 1995. Diagenetic processes and nutrient fluxes at the sediment-water interface, Northern Adriatic Sea, Italy. Mar. Fresh. Res., 46: 55-67.

Berner, R.A. - 1976. Inclusion of adsorption in the modeling of early diagenesis. Earth Planet. Sci. Lett., 29: 333-340.

Berner, R.A., K.C. Ruttenberg, E.D. Ingall and J.-L. Rao. - 1993. The nature of phosphorus burial in modern marine sediments. In: R. Wollast, F.T. Mackenzie and L. Chou (eds.), Interactions of $C, N, P$ and $S$ Biogeochemical Cycles and Global Change, pp. 365-378. NATO ASI Series, Vol. 4, Springer-Verlag, Berlin Heidelberg.

Black, K.S., G.R. Fones, O.C. Peppe, H.A. Kennedy and I. Bentaleb. - 2001. An autonomous benthic lander: preliminary observations from the UK BENBO thematic programme. Cont. Shelf Res., 21: 859-877.

Callender, E. and D.E. Hammond. - 1982. Nutrient exchange across the sediment-water interface in the Potomac River estuary. Estuar. Coast. Shelf Ser., 15: 395-413.

Charpy-Roubaud, C., L. Charpy and G. Sarazin. - 1996. Diffusional nutrient fluxes at the sediment-water interface and organic matter mineralization in an atoll lagoon (Tikehau, Tuamotu Archipelago, French Polynesia). Mar. Ecol. Prog. Ser., 132: 181-190.

Clavero, V., F.X. Niell and J.A. Fernández. - 1991. Effects of Nereis diversicolor O. F. Muller abundance on the dissolved phosphate exchange between sediment and overlying water in Palmones River estuary (Southern Spain). Estuar. Coast. Shelf Sci., 33: 193-202.

Clavero, V., J.J. Izquierdo, J.A. Fernández and F.X. Niell. - 2000. Seasonal fluxes of phosphate and ammonium across the sed- 
iment-water interface in a shallow small estuary (Palmones river, Southern Spain). Mar. Ecol. Prog. Ser., 198: 51-60.

Colman, A.S. and H.D. Holland. - 2000. The global diagenetic flux of phosphorus from marine sediments to the oceans: redox sensitivity and the control of atmospheric oxygen levels. In C.R. Glenn, J. Lucas and L. Prévôt-Lucas (eds.), Marine Authigenesis: from Global to Microbial. SEPM Spec. Pub., 66: 53-75.

Delaney, M.L. - 1998. Phosphorus accumulation in marine sediments and oceanic phosphorus cycle. Global Biogeochim. Cycles, 12(4): 563-572.

DOE. - 1994. Handbook of methods for the analysis of the various parameters of the carbon dioxide system in sea water; version 2, A.G. Dickson and C. Goyet, (eds.). ORNL/CDIAC-74.

Doering, P.H., J.R. Kelly, C.A. Oviatt and T. Sowers. - 1987. Effect of the hard clam Mercenaria mercenaria on benthic fluxes of inorganic nutrients and gases. Mar. Biol., 94: 377-383.

El Rayis, O.A. - 1985. Re-assessment of the tritation methods for determination of organic carbon in recent sediments. Rapp. Comm. Int. Mer Mediter., 29: 45-47.

Forja, J.M. and A. Gómez-Parra. - 1998. Measuring nutrient fluxes across the sediment-water interface using benthic chambers. Mar. Ecol. Prog. Ser., 164: 95-105.

Forja, J.M., J. Blasco and A. Gómez-Parra. - 1994. Spatial and seasonal variations of "in situ" benthic fluxes in the Bay of Cádiz (SW Spain). Estuar. Coast. Shelf Sci., 39: 127-141.

Giordani, P. and D.E. Hammond. - 1985. Techniques for measuring benthic fluxes of ${ }^{222} \mathrm{Rn}$ and nutrients in coastal waters. Consiglio Nazionale delle Ricerche Istituto per la Geologia Marina. Bologna, Rapporto Tecnico N. 20: 1-33.

Gómez-Parra, A. and J.M. Forja. - 1992. Significance of benthic regeneration in nutrient balance in the Bay of Cádiz, south-west Spain (a shallow semi-closed coastal ecosystem). Sci. Total Environ. Suppl., 1992: 1079-1086.

Gómez-Parra, A. and J.M. Forja. - 1993. Benthic nutrient fluxes in Cadiz Bay (SW Spain). Hydrobiologia, 252: 23-34.

Grandel, S., D. Rickert, M. Schlüter and K. Wallmann. - 2000. Pore-water distribution and quantification of diffusive benthic fluxes of silicic acid, nitrate and phosphate in surface sediments of the deep Arabian Sea. Deep-Sea Res. II, 47: 2707-2734.

Grasshoff, K., M. Ehrhardt and K. Kremling. - 1983. Methods of seawater analysis, 2nd ed. Verlag-Chemie, Weinheim.

Hammond, D.E., C. Fuller, D. Harmon, B. Hartman, M. Korosec, L.G. Miller, R. Rea, S. Warren, W.M. Berelson and S.W. Hager. - 1985. Benthic fluxes in San Francisco Bay. Hydrobiologia, 129: 69-90.

Ingall, E. and R. Jahnke. - 1997. Influence of water-column anoxia on the elemental fractionation of carbon and phosphorous during sediment diagenesis. Mar. Geol., 139: 219-229.

Ingall, E.D., R.M. Bustin and P. Van Cappellen. - 1993. Influence of water column anoxia on the burial and preservation of carbon and phosphorous in marine shales. Geochim. Cosmochim. Acta, 57: 303-316.

Istvanovics, V. and K. Pettersson. - 1998. Phosphorus release in relation to composition and isotopic exchangeability of sediment phosphorus. Arch. Hydrobiol. Spec. Issues Advanc. Limnol., 51: 91-104.

Jensen, H.S., K.J. McGlathery, R. Marino and R.W. Howarth. - 1998. Forms and availability of sediment phosphorus in carbonate sand of Bermuda seagrass beds. Limnol. Oceanogr., 43: 799-810.

Klump, J.V. and C.S. Martens. - 1981. Biogeochemical cycling in an organic rich coastal marine basin - II. Nutrient sedimentwater exchange processes. Geochim. Cosmochim. Acta., 45: 101-121.

Koch, M.S. - 1997. Rizhofora mangle L. seedling development into the sampling stage across resources and stress gradients in subtropical Florida. Biotropica, 29: 427-439.

Koch, M.S., R.E. Benz and D.T. Rudnick. - 2001. Solid-phase phosphorus pools in highly organic carbonate sediments of Northeastern Florida Bay. Estuar. Coast. Shelf, 52: 279-291.

Koroleff, F. - 1983. Determination of nutrients. In: K. Grasshoff, M. Ehrhardt and K. Kremling (eds.), Methods of seawater analysis, $2^{\text {nd }}$ ed., pp. 125-187. Verlag-Chemie, Weinheim.

Krom, M.D. and R.A. Berner. - 1980. The diffusion coefficients of sulfate, ammonium, and phosphate ions in anoxic marine sediments. Limnol. Oceanogr., 25(2): 327-337.

Lerman, A. - 1976. Migration processes and chemical reactions in intertidal waters. In: E.D. Golberg, I.N. McCave, J.J. O’Brien and J.H. Steele (eds.), The Sea, pp. 695-738. Wiley, N.Y.

López, P., M. Vidal, X. Lluch and J.A. Morguí. - 1995. Sediment metabolism in a transitional continental-marine area: The Albufera of Majorca (Balearic Islands, Spain). Mar. Freshwater Res., 46: 45-53.

Louchouarn, P., M. Lucotte, E. Duchemin and A. De Vernal. 1997. Early diagenetic processes in recent sediments of the Gulf of St-Lawrence: phosphorus, carbon and iron burial rates. Mar. Geol., 139: 181-200.

Lucotte, M., A. Mucci, C. Hillaire-Marcel and S. Tran. - 1994 Early diagenetic processes in deep Labrador Sea sediments: reactive and non-reactive iron and phosphorus. Can. J. Earth Sci., 31: 14-27.

Lyons, W.B., T.C. Loder and S.M. Murray. - 1982. Nutrient pore water chemistry, Great Bay, New Hampshire: Benthic fluxes. Estuaries, 5(3): 230-233

McCaffrey, R.J., A.C. Myers, E. Davey, G. Morrison, M. Bender, N. Luedtke, D. Cullen, P. Froelich and G.P. Klinkhammer. 1980. The relation between pore water chemistry and benthic fluxes of nutrients and manganese in Narragansett Bay, Rhode Island. Limnol. Oceanogr., 25(1): 31-44.

McManus, J., W.M. Berelson, K.H. Coale, K.S. Jonhson and T.E. Kilgore. - 1997. Phosphorus regeneration in continental margin sediments. Goechim. Cosmochim. Acta, 16 (14): 2891-2907.

Morse, J.W. - 1974. Calculation of diffusive fluxes across the sediment-water interface. J. Geophys. Res., 79(33): 5045-5048.

Murray, J.W., V. Grundmains and W.M. Smethie. - 1978. Interstitial waters chemistry in the sediments of Saanich Inlet. Geochim. Cosmochim. Acta, 42: 1011-1026.

Pardo, P., J.F. López-Sánchez, G. Rauret, V. Ruban, H. Muntau and $\mathrm{Ph}$. Quevauviller. - 1999. Study of the stability of extractable phosphate content in a candidate reference material using a modified Williams extraction procedures. Analyst, 124: 407-411.

Pettersson, K., B. Boström and O.-S. Jacobsen. - 1988. Phosphorous in sediments - speciation and analysis. Hydrobiologia, 170: 91-101.

Petticrew, E.L. and J.M. Arocena. - 2001. Evaluation of iron-phosphate as a source of internal lake phosphorous loadings. Sci. Total Environment, 266: 87-93.

Ruban, V., J.F. López-Sánchez, P. Pardo, G. Rauret, H. Muntau and Ph. Quevauviller. - 1999. Selection and evaluation of sequential extraction procedures for the determination of phosphorus forms in lake sediment. J. Environ. Monit., 1: 51-56.

Ruttenberg, K.C. - 1992. Development of a sequential extraction method for different forms of phosphorus in marine sediments. Limnol. Oceanogr., 37 (7): 1460-1482.

Ruttenberg, K.C. - 1993. Reassessment of the oceanic residence time of phosphorus. Chem Geol., 107: 405-409.

Ruttenberg, K.C. and R.A. Berner. - 1993. Authigenic apatite formation and burial in sediments from non-upwelling, continental margin environments. Geochim. Cosmochim. Acta, 57: 991-1007.

Sáenz, V. - 1998. Distribución espacial y especiación de metales pesados en sedimentos de tres sistemas litorales del Golfo de Cádiz. PhD Thesis, Univ. of Cádiz.

Shepard, F.P. - 1954. Nomenclature based on sand-silt-clay ratios. J. Sed. Pet., 24: 151-158.

Sundy, B., C. Gobeil, N. Silverberg and A. Mucci. - 1992. The phosphorus cycle in coastal marine sediments. Limnol. Oceanogr., 37(6): 1129-1145.

Sweerts, J.P.R.A., M.J. Baer-Gilissen and A.A. Cornelese. - 1991. Oxygen-consuming processes at the profundal and littoral sediment-water interface of a small meso-eutrophic lake (Lake Vechten, The Netherlands). Limnol. Oceanogr., 36: 1124-1133.

Turner, D.R., M Whitfield and A.G. Dickson. - 1981. The equilibrium speciation of dissolved components in freshwater and seawater in at $25^{\circ} \mathrm{C}$ and $1 \mathrm{~atm}$ pressure. Geochim. Cosmochim. Acta, 45: 855-881.

Vidal, M. - 1988. Dynamics and content of phosphorus in the sediment of seagrass meadows. Oceologia Aquatica, 9: 41-59.

Vink, S., R.M. Chambers and S.V. Smith. - 1997. Distribution of phosphorus in sediments from Tomales Bay, California. Mar. Geol., 139: 157-179.

Received November 1, 2008. Accepted July 30, 2010.

Published online November 13, 2010. 